\title{
The Historical Background of the Communist Manifesto
}

\author{
George R. Boyer
}

$\Gamma$

The Manifesto of the Communist Party, published 150 years ago in London in February 1848, is one of the most influential and widely-read documents of the past two centuries. The historian A. J. P. Taylor (1967, p. 7) has called it a "holy book," and contends that because of it, "everyone thinks differently about politics and society." And yet, despite its enormous influence in the 20th century, the Manifesto is very much a period piece, a document of what was called the "hungry" 1840s. It is hard to imagine it being written in any other decade of the 19th century. The critique of capitalism offered by Marx and Engels in the Manifesto is understandable in the context of economic conditions in Britain from 1837 to 1848 , and it is not that different, in places, from the conclusions reached by other social critics during the 1840s.

This paper attempts to place the Manifestos analysis of capitalist economic development in historical perspective. I begin by summarizing the economic arguments of Marx and Engels. While the Manifesto-was written by Marx, its economic analysis was strongly influenced by Engels's "practical experience of capitalism" in his family's cotton firm in Manchester, England, in 1842-44. Upon his return to Germany, Engels published in 1845 a scathing indictment of early industrial capitalism, The Condition of the Working Class in England. Much of Engels's critique of British capitalism reappears in greatly condensed form in Section I of the Manifesto. The second part of the paper examines the economic, social, and political conditions in Manchester and the surrounding south Lancashire cotton towns in the 1830 s and 1840s, drawing largely on the views of contemporary observers. I then

- George R. Boyer is Associate Professor of Labor Economics, New York State School of Industrial and Labor Relations, Cornell University, Ithaca, New York. His e-mail address is (grb3 @Cornell, edu). 
look at recent research on the standard of living of the working class from 1820 to 1851, focusing on conditions in the Lancashire cotton industry during the "hungry '40s." Finally, I examine economic conditions in England in the two or three decades after the Manifesto was published, and briefly discuss why Marx and Engels's predictions for the imminent collapse of capitalism were so wide of the mark.

\section{The Economic Arguments in the Communist Manifesto and their Sources}

When the Communist Manifesto was written, Karl Marx and Friedrich Engels were both in their late 20s. Marx, the son of a prosperous German lawyer, was living in Brussels, having emigrated from Prussia to Paris in 1843 after the government had suppressed the newspaper which he edited, and having been expelled from Paris in 1845. Engels, whose father owned a cotton spinning business with branches in Barmen, Germany, and Manchester, England, was living in Paris. The two had first met in 1842, and had begun to work together after their second meeting in Paris in 1844. They had written two books together, The Holy Family (1845) and The German Ideology (1846), before writing the Communist Manifesto.

In Brussels, Marx established a Communist Correspondence Committee to maintain contact with German, French and English socialists. The committee created ties with a group of German communists in London, the League of the Just, and in January 1847 the League invited Marx and Engels to become members. In November 1847, Marx and Engels attended a congress of the renamed Communist League held in London, and Marx appears to have dominated the proceedings. At the end of the conference they were invited to write a manifesto stating the League's doctrines. Marx wrote the Manifesto in December 1847 and January 1848. The Manifesto was published in London in February, just as the 1848 revolutions were beginning across Europe, but it appears to have had little if any influence on the revolutions. $^{2}$

In Section 1 of the Manifesto, entitled "Bourgeois and Proletarians," Marx and Engels present a description of the development of industrial capitalism, and predic-

\footnotetext{
' The early careers of Marx and Engels are discussed in McLellan (1973, chapters 1-3) and Henderson (1976, chapters 1-3). The Holy Family, published in February 1845, largely was an attack on the philosopher Bruno Bauer, a member of the Young Hegelians. The German Ideology which McLellan (1973, p. 151) considers one of Marx and Engels's most important works because of its detailed discussion of the "materialist conception of history," was rejected by at least seven publishers in 1846-47 and was not in fact published until the 20th century. Not long after the publication of the Manifesto, Marx was expelled from Belgium, and moved to Cologne to assume the editorship of a radical newspaper. When the newspaper was suppressed by the Prussian authorities in the spring of 1849, he moved to London, where he lived until his death in 1883. Engels moved to Britain in 1850, and worked for his family's cotton firm in Manchester until 1869, when he retired and moved to London. He died in 1895.

For a detailed discussion of the formation of the Communist League and the background of the Manifesto, see McLellan (1973, pp. 167-88). Other useful commentaries on the Manifesto can be found in Taylor (1967) and Struik (1971).
} 
tions for its future. They begin by declaring that "the history of all hitherto existing society is the history of class struggles" (1848 [1992], p. 3). In the modern historical epoch, the epoch of the bourgeoisie, the class struggle had been simplified-there were now only "two great classes," the bourgeoisie and the proletariat. Since the industrial revolution, the bourgeoisie had captured political control; "the executive of the modern state is but a committee for managing the common affairs of the whole bourgeoisie." Once in control, the bourgeoisie "pitilessly" put an end to all feudal and patriarchal relationships between employers and workers, and "left remaining no other nexus between man and man than naked self-interest, than callous 'cash payment'. . . . for exploitation, veiled by religious and political illusions, it has substituted naked, shameless, direct, brutal exploitation" (p. 5).

The bourgeoisie brought about the industrial revolution. It revolutionized the instruments of production by improving machinery, and by destroying old industries and creating new ones. It created enormous cities, replaced existing relations of property with free competition, centralized the means of production, and created a world market for its products. While condemning the bourgeoisie for its "brutal exploitation" of labor, Marx and Engels (1848 [1992], pp. 5-8) praise it for showing "what man's activity can bring about. It has accomplished wonders far surpassing Egyptian pyramids, Roman aqueducts, and Gothic cathedrals.. . . The bourgeoisie, during its rule of scarce one hundred years, has created more massive and more colossal productive forces than have all preceding generations together."

Business cycles were another creation of the modern epoch. These recurring crises of overproduction put on trial, "each time more threateningly, the existence of the entire bourgeois society." The bourgeoisie surmount these crises by finding new markets to exploit and by increasing their exploitation of existing markets. However, their actions pave the way "for more extensive and more destructive crises, and . . . [diminish] the means whereby crises are prevented" (Marx and Engels, 1848 [1992], pp. 8-9).

The epoch of the bourgeoisie also brought about the development of the proletariat - the modern industrial working class. Under modern capitalism, the workers were forced to "sell themselves piecemeal" to the bourgeoisie; they "live only so long as they find work, and . . . find work only so long as their labour increases capital. . . . [They] are consequently exposed to all the vicissitudes of competition, to all the fluctuations of the market" (Marx and Engels, 1848 [1992], p. 9). As a result of mechanization, the laborer had become a mere "appendage of the machine." The increased use of machinery and the division of labor reduced "the skill and exertion of strength implied in manual labour," which enabled the bourgeoisie to replace the labor of adult males with that of women and children. Finally, "modern industry has converted the little workshop of the patriarchal master into the great factory of the industrial capitalist. Masses of labourers, crowded in the factory, are organized like soldiers" (p. 10). Ironically, the condition of the proletariat deteriorated as capitalism progressed: "the modern labourer . . . becomes a pauper, and pauperism develops more rapidly than population and wealth" (p. 15). 
From its conception, the proletariat had struggled with the bourgeoisie. At first their resistance took the form of isolated acts of machine breaking and arson. However, the advance of industry, and in particular the concentration of the proletariat in large factories, led workers to form trade unions and friendly societies. Eventually the proletarians formed their own political party, which "compels legislative recognition of particular interests of the workers, by taking advantage of the divisions among the bourgeoisie itself (Marx and Engels, 1848 [1992], pp. 11-12). As the condition of the working class continues to deteriorate, at some point it will become clear that the bourgeoisie is not fit to rule society, and then the "veiled civil war, raging within existing society. . . breaks out into open revolution." The proletariat will overthrow the bourgeoisie, and destroy private property. This process is inevitable: "The development of modern industry . . . cuts from under its feet the very foundation on which the bourgeoisie produces and appropriates products. What the bourgeoisie, therefore, produces, above all, is its own grave-diggers" (pp. 15-16).

The remaining three sections of the Manifesto "belong to the historian of political thought rather than to the historian of economic analysis," as Schumpeter (1949, p. 201) wrote, and can be quickly summarized. Section 2 states that the aims of the communists "may be summed up in the single sentence: Abolition of private property" (Marx and Engels, 1848 [1992], p. 18). It concludes with a list of ten reforms that the communists would undertake, including the expropriation of all land rent, institution of a "heavy progressive" tax, abolition of the right of inheritance, centralization of credit and transport in the hands of the state, and free public education for all children (pp. 25-26). Section 3 is a critique of other forms of socialism: reactionary, conservative or bourgeois, and Utopian. Finally, Section 4, which is only two pages long and apparently unfinished-Marx was under pressure from the Communist League to finish the Manifesto-states the position of the communists with regards to existing opposition parties in Europe. The communists support revolutionary movements to overthrow forcibly existing social orders throughout Europe. The Manifesto concludes with the famous words: "The proletarians have nothing to lose but their chains. They have a world to win. Working men of all countries, unite!" (p. 39).

In writing the economic and historical analysis contained in Section 1 of the Manifesto, Marx borrowed heavily from a catechism of 25 questions and answers written by Engels in October 1847 and entitled "Principles of Communism." ${ }^{3}$ In particular, Marx's discussion of the process of industrialization, the development of the bourgeoisie and the proletariat, and the causes and consequences of business cycles in the Manifesto is largely drawn from the answers to questions 4, 11, 12, and 13 of Engels's "Principles." The discussion of these issues contained in the "Principles," in turn, was a summary of material from Engels's 1845 book, The Condition of the Working Class in England. David McLellan, Marx's biographer, maintains that

' Engels's "Principles of Communism" are included in Struik (1971, pp. 169-89). 
Engels's book provided "an empirical basis for several of Marx's later theories. It was the foundation document of what was to become the Marxian socialist tradition" (1993, pp. xix-xx). It is therefore useful to briefly summarize the analysis of capitalist development put forward by Engels. ${ }^{4}$

According to Engels (1845 [1987], pp. 116, 159), the introduction of machinery and the division of labor that occurred as a result of the industrial revolution greatly increased productivity, but "every improvement in machinery throws workers out of employment, and the greater the advance, the more numerous the unemployed." The class of workers "most ill-used" by the introduction of machinery was the handloom cotton weavers, thousands of whom had become poverty-stricken as a result of the adoption of the power loom. The increased use of machinery also enabled the bourgeoisie to replace adult male workers with women and children, who were employed at far lower wages. As a result, "wages in general have been reduced by the improvement of machinery" (pp. 161-64).

The "centralizing tendency of competition," Engels argued, brought about the rise of business cycles; every five years or so a crisis occurred. During each crisis many small manufacturers failed, while large manufacturers closed their mills or went to short time. Despite sharp increases in charity and poor relief expenditures in response to increasing unemployment, "want becomes universal among the workers." After a year or two of depression, prosperity returned, and the demand for labor increased. As a result of the sharp fluctuations in labor demand, "English manufacture must have, at all times save the brief periods of highest prosperity, an unemployed reserve army of workers, in order to be able to produce the masses of goods required by the market in the liveliest months." When they were not employed in the factories, the members of the reserve army lived by huckstering, peddling, performing occasional odd jobs, begging or stealing (Engels, 1845 [1987], pp. 117-19).

The development of capitalism led to the creation of great manufacturing towns, to which huge numbers of agricultural laborers and Irishmen migrated in search of employment. The living conditions in these cities were horrible. The working class was crowded into slums, in which the housing was poorly constructed, badly ventilated, and in a bad state of repair. Most of these slums did not have an adequate water supply and were completely lacking in drainage facilities (Engels, 1845 [1987], pp. 100-2). It is no surprise, therefore, that death rates were extremely high in the industrial cities. In Manchester, one out of every 30.8 persons died per year, compared to one in 45 for England and Wales (pp. 135-37). The working conditions in the cotton factories, in particular the long hours standing at work in damp, warm, and badly ventilated rooms, also were gready injurious to the health of workers, especially women and children (pp. 171-75). The "hateful greed of the manufacturers" resulted in "women made unfit for childbearing, children de-

\footnotetext{
${ }^{4}$ Two useful commentaries on Engels's book, written from greatly different perspectives, are Henderson and Chaloner (1958) and Marcus (1974).
} 
formed, men enfeebled, limbs crushed, whole generations wrecked, afflicted with disease and infirmity" (pp. 183-84). Engels maintained that, because the bourgeoisie did nothing to ameliorate the living and working conditions of the working class, it was guilty of "social murder" (p. 138).

The bourgeoisie achieved political dominance with the passage of the Reform Act of 1832, which enfranchised middle-class property holders and increased the representation of the industrial districts in Parliament. Engels (1845 [1987], p. 275) declared the bourgeoisie as a class to be "incurably debased by selfishness." The adoption of the New Poor Law in 1834, which forced ablebodied paupers and their families into workhouses, was an "open declaration of war" against the proletariat (pp. 281-85). The revolt of the proletariat against the bourgeoisie began early in the industrial revolution, and by 1844 had passed through several stages, from crime, to machine-breaking and arson, to trade unionism. Unions represented "the first attempt of the workers to abolish competition." They greatly nourished the workers' hatred of the bourgeoisie, and the bourgeoisie in turn constantly tried to destroy the unions (pp. 224-31). Unionism was especially powerful in those branches of industry in which the factory system predominated. Thus, "Lancashire, and especially Manchester, is the seat of the most powerful unions" (p. 245).

Lancashire also was the center of Chartism, the working-class movement for political reform which began in the spring of 1838 with the publication of the People's Charter, a petition to Parliament demanding, among other things, universal manhood suffrage, equal electoral constituencies, the payment of members of Parliament, and the abolition of the requirement that members of Parliament be property owners. Engels maintained that the Chartists' demands were "sufficient to overthrow the whole English Constitution" (1845 [1987], p. 236). The spread of Chartism was greatly accelerated by the New Poor Law, which intensified the proletariat's hatred of the property-holders. At the conclusion of the book, Engels predicted that the next crisis, in 1846 or 1847, would lead to the adoption of the Chartist proposals, and that the following crisis, in 1852 or 1853 , would lead to a revolution of the proletariat against the bourgeoisie (pp. 290-91). The collapse of capitalism in the near future was "as certain as a mathematical or mechanical demonstration" (p. 63).

The fact that so much of the economic and historical analysis in the Manifesto can be traced back to Engels's earlier book suggests that economic developments in England provided the model on which Marx's analysis was based. In the preface to the first German edition of The Condition of the Working Class, Engels (1845 [1987], p. 29) asserted that "proletarian conditions exist in their classical form, in their perfection, only in the British Isles, particularly in England proper." Other countries had begun to industrialize, but their economic development lagged far behind that of Britain. In 184047.3 percent of Britain's adult male labor force was employed in industry; no other western European country employed that large a share in industry before 1900 (Crafts, 1985, pp. 57-59).

The "classical" proletarian conditions noted by Engels existed for only a mi- 
nority of English workers. McCloskey (1981, p. 109) contends that as late as 1861 only 30 percent of the labor force "was employed in activities that had been radically transformed in technique since 1780 . . . Britain was not in 1861 a cotton mill." Large-scale factory production was limited to a small number of sectors of the economy, one of which was cotton textiles. The cotton industry was located mainly in south Lancashire, and centered on the city of Manchester.

The fact that Engels's family happened to own a cotton mill in Manchester is one of the interesting accidents of history. The historian Asa Briggs (1963, p. 113) stressed that Manchester, with its large factories and "alarming social relationships," was not a typical British industrial city. It is useful to compare Manchester with Birmingham, the second largest industrial city in England in the 1840s. Alexis de Tocqueville visited both cities in 1835. He wrote that Manchester contained "a few great capitalists, thousands of poor workmen and little middle class," while Birmingham contained "few large industries, many small industrialists." In Manchester, "workmen are counted by the thousand, two or three thousand in the factories. At Birmingham the workers work in their own houses or in little workshops in company with the master himself." $\mathrm{He}$ concluded that "the working people of Birmingham seem more healthy, better off, more orderly and more moral than those of Manchester" (1835 [1958], pp. 104-5). Briggs (1963, p. 113) speculated that, "if Engels had lived not in Manchester but in Birmingham, his conception of 'class' and his theories of the role of class in history might have been very different. In this case Marx might have been not a communist but a currency reformer." Similarly, McLellan (1993, p. xviii) wrote that if Engels "had spent more time in London, where manufacture was still dominated by artisans, he would have got a different picture" of the development of capitalism.

Engels himself noted many years later (as quoted in McLellan, 1993, p. xii) the importance his time in Manchester in 1842-44 had for his intellectual development:

[In Manchester] it was forcibly brought to my notice that economic factors, hitherto ignored or at least underestimated by historians, play a decisive role in the development of the modern world. I learnt that economic factors were the basic cause of the clash between different classes in society. And I realized that in a highly industrialized country like England the clash of social classes lay at the very root of the rivalry between parties and was of fundamental significance in tracing the course of modern history.

In sum, the economic and historical analysis contained in the Communist Manifesto largely is derived from Engels's description of the development of the cotton textile industry in south Lancashire in the first half of the nineteenth century, and of social and political conditions in Manchester in the 1840s. To place the arguments of the Manifesto' $m$ historical perspective, it therefore is necessary to examine the economic, social, and political conditions in south Lancashire during the "hungry '40s." 


\section{Contemporary Views of Conditions in Manchester in the 1830s and $1840 \mathrm{~s}$}

Much was written about Manchester in the 1830s and 1840s, and much of what was written was unfavorable. Tocqueville wrote that, at Manchester, "humanity attains its most complete development and its most brutish; here civilisation works its miracles, and civilised man is turned back almost into a savage" (1835 [1958], p. 108). Charles Dickens visited Manchester in 1838, and wrote that "what I have seen has disgusted and astonished me beyond all measure;" a year later, Sir Charles Napier referred to Manchester as "the chimney of the world . . . the entrance to hell realized" (both quoted in Marcus, 1974, pp. 30, 46). Asa Briggs (1963, p. 85) wrote that when Engels arrived in Manchester in the fall of 1842, the city "was already associated . . . with industry, with newness, with squalor, and, above all else, with unfamiliar and, on occasion, alarming social relationships." According to Briggs (1963, pp. 51, 93), "every age has its shock city." Just as Chicago, with its slums and ethnic problems, was the shock city of the 1890s, Manchester was "the shock city of the 1840s, attracting visitors from all countries, forcing to the surface what seemed to be intractable problems of society and government, . . . of 'class', of the relations between rich and poor."

Manchester was the center of the cotton industry. Engels (1845 [1987], p. 82) referred to Manchester as "that classic soil on which English manufacture has achieved its masterwork" and wrote that, "in the cotton industry of south Lancashire, the application of the forces of Nature, the superseding of hand-labour by machinery . . . and the division of labour, are seen at the highest point." By the standards of the day, cotton factories were quite large. An 1841 survey of 128 cotton firms in Manchester found that 32 percent of the cotton work force were employed in firms with 500 or more workers (Lloyd-Jones and Le Roux, 1980, pp. 75-76). The concentration of workers in large firms was even more pronounced in other south Lancashire cities in 1841: in Ashton-under-Lyne and Preston, 56 percent and 48 percent of cotton workers were employed in mills with 500 or more workers (Howe, 1984, p. 47; Huberman, 1996, p. 56). While the typical cotton firm employed between 150 and 500 workers, two-thirds of the engineering firms in Britain in 1851 employed ten or fewer workers, and the Birmingham metal trades and Sheffield cutlery trades also were "workshop industries" (Crouzet, 1985, p. 35; Berg, 1994, pp. 136-39). In the Manifesto, when Marx and Engels (1848 [1992], p. 10) speak of "the great factory of the industrial capitalist [in which] masses of labourers . . . are organized like soldiers," they are referring to a cotton mill.

The city's squalor was publicized in James Kay's classic 1832 book, The Moral and Physical Condition of the Working Classes employed in the Cotton Manufacture in Manchester, and in Joseph Adshead's Distress in Manchester, published in 1842. Kay (1832, p. 27) wrote that the streets in working class districts typically were "untraversed by common sewers;" the houses of the laboring population were often damp, "ill ventilated, unprovided with privies, and, in consequence, the streets which are narrow, unpaved, 
and worn into deep ruts, become the common receptacles of mud, refuse, and disgusting ordure." These living conditions encouraged a "predisposition to contagious disease" such as cholera. Writing a decade later, Adshead (1842, pp. 46, 50) concluded that "destitution in its most rigorous form prevails to an appalling extent in Manchester," and he cited a local doctor who wrote that "no inconsiderable portion of our fellow-creatures is living on food and in dwellings scarcely fit for brutes."

The high death rates that resulted from the destitution of Manchester's laboring population were documented in Edwin Chadwick's (1842 [1965]) influential Report on the Sanitary Condition of the Labouring Population of Great Britain. Chadwick presented evidence that the average age of death of "mechanics, labourers, and their families" in Manchester was 17, as compared to 38 in rural Rutlandshire; this despite the fact that laborers' wages were at least twice as high in Manchester as in Rutland. The major cause of the low life expectancy was Manchester's appallingly high child mortality rates; 57 percent of children born in Manchester to working class parents died before their fifth birthday (pp. 222-23). These studies were well known to Marx and Engels. Engels's description of the Manchester slums largely was drawn from Kay's book, and he used data reported by Chadwick to demonstrate the effects of poor living conditions in industrial cities on death rates.

Economic conditions in south Lancashire also clearly revealed to Marx and Engels the potentially devastating effects of cyclical downturns. When Engels arrived in Manchester in the late fall of 1842, Britain was just beginning to recover from the deep depression of 1841-42. The downturn was particularly severe in the cotton industry; the consumption of raw cotton declined in both years, the only time it fell for two consecutive years between the end of the Napoleonic wars and the cotton famine of 1861-65. A large number of cotton firms went bankrupt, throwing thousands of factory operatives out of work. Lancashire factory inspectors estimated that 15 percent of cotton factory operatives were unemployed in the last quarter of 1841 (Matthews, 1954, pp. 141-43). Conditions in south Lancashire continued to deteriorate in the spring and summer of 1842. In November, when Engels arrived in Manchester, "there were crowds of unemployed working men at every street corner, and many mills were still standing idle" (Engels, 1845 [1987], pp. 121-22). Another serious downturn hit Britain in 1847-48, and once again thousands of Lancashire cotton operatives lost their jobs. The Economist reported that in the first six months of 1848, 18.6 percent of the workforce in Manchester's cotton mills was unemployed, and another 9.5 percent was on short time (Boyer, 1990, p. 235).

During the downturns of 1841-42 and 1847-48, many unemployed factory operatives were forced to turn to the poor law and private charity for assistance. In response to the "extreme destitution" faced by thousands of Manchester families in 1842, poor relief expenditures increased sharply, and voluntary subscriptions for bedding, clothing, and soup kitchens were undertaken. Adshead (1842, pp. 40-41) estimated that up to 3,000 persons per day were supplied with soup during the summer of 1842, and concluded that "but for this very timely relief many might have been reduced to absolute starvation." On July 9, 1842, the Manchester Times (quoted in Read, 1959, p. 53) wrote that "any man passing through the district and 
observing the condition of the people, will at once perceive the deep and ravaging distress that prevails . . . The picture which the manufacturing districts now present is absolutely frightful." In the second week of July 1847, about 10 percent of Manchester's population was being granted poor relief (Boot, 1990, p. 220).

Lancashire also provided Marx and Engels with the classic example of the technological unemployment associated with industrialization, the decline of handloom weaving. In the late 18th century technological improvements in spinning had led to a sharp increase in the demand for handloom weavers. By the early $1820 \mathrm{~s}$ there were approximately 200,000 handloom weavers living in Lancashire and Cheshire, equal to about 25 percent of the adult male labor force in these counties (Lyons, 1989, pp. 48-49). Although piece rates began to decline in the 1790s, handloom weaving had continued to provide a reasonable livelihood during the first 15-20 years of the 19th century. However, the widespread adoption of the power loom caused the wages of handloom weavers to decline by 60 percent or more from 1820 to 1840 . By the 1830 s weavers had become "among the most poverty-stricken workers" in northern England (Brown, 1990, p. 610; Lyons, 1989, pp. 52, 62). There were still about 100,000 weavers in Lancashire in 1841, the year before Engels arrived in Manchester. The poverty of these remaining weavers was so great that many Lancashire poor law unions continued to pay them allowances-inaid-of-wages long after this form of relief had been oudawed by the Poor Law Amendment Act of 1834 (Bythell, 1969, ch. 10; Rose, 1966). The handloom weavers' economic plight "cast a pall over the entire period and over all the working classes" (Himmelfarb, 1984, p. 137).

For many commentators the most disturbing thing about south Lancashire was its class relations, and in particular the "rioting propensities" of its working class. The cotton industry experienced major strikes in 1808, 1810, 1818, and 1829-30, and rashes of machine breaking in 1811-12 and 1826 (Hammond and Hammond, 1919, pp. 72-135; Charlesworth et al., 1996, pp. 42-50). In March 1817 a large number of Manchester workers, the so-called Blanketeers, determined to march to London to demand Parliamentary reform, and some of their number plotted to start an insurrection by burning Manchester.

The event which contemporaries most associated with Manchester, however, was the infamous "Peterloo Massacre" of August 16, 1819. On that date several thousand workers from Manchester and the surrounding cotton towns assembled in St. Peter's Field at a mass meeting for Parliamentary reform. Local magistrates, fearing a riot, employed the yeomanry and the cavalry to break up the meeting, and in the struggle that followed eleven workers were killed and about 400 injured.

Parliament's adoption of the Poor Law Amendment Act in 1834 greatly increased class antagonism in the industrial cities of northern England. Many workers viewed the New Poor Law, which stated that able-bodied paupers and their families should be relieved only in well-regulated workhouses, as a betrayal of an unwritten "social contract" and an attempt to "punish poverty." In 1837, when the Poor Law Commission attempted to set up poor law unions in the industrial north, it was met by strong opposition. Public meetings denouncing the law were held throughout 
the textile district, the Assistant Poor Law Commissioner and local officials were threatened and harassed in several cities, and local elections for Boards of Guardians were boycotted or disrupted. The South Lancashire Anti-Poor Law Association, formed in November 1837, collected nearly 123,000 signatures to a petition calling for the repeal of the New Poor Law (Edsall, 1971; Knott, 1986). When Parliament rejected a motion for repeal, many of the leaders of the anti-poor law movement turned their attention to parliamentary reform and, in particular, to Chartism. Still, workers' hatred of the New Poor Law and of the workhouse "bastilles" remained strong when Engels arrived in Manchester in 1842.

The early centers of Chartism were London and Birmingham, but the movement soon spread to the northern industrial cities. Two associations founded in Manchester in 1838, the Manchester Universal Suffrage Association and the Manchester Political Union, sponsored a series of large-scale demonstrations in favor of the Charter in the summer of 1838 , one of which was attended by nearly 50,000 people, making it the largest demonstration since Peterloo. The movement declined for a time following Parliament's overwhelming rejection of the Charter in 1839 , but it revived in south Lancashire in the summer of 1840, and progressed rapidly during the depression of 1841-42. Over 300,000 Lancashire individuals signed the national petition presented to Parliament in 1842; just under 100,000 signatures came from Manchester (Read, 1959, pp. 43-44, 50-52). Parliament rejected the second National Petition for the Charter in April 1842. Partly as a result of this, and partly because of the deepening economic distress, the workers of south Lancashire turned to direct industrial action in the summer of 1842. In response to a few employers' threats to cut wage rates, on August 7 a mass meeting of up to 10,000 operatives near Stalybridge called for a general strike to achieve "a fair day's wage for a fair day's work" and the passage of the Charter. The strike spread first to Manchester and then all over south Lancashire, with crowds of roving strikers "using as much force as was necessary to bring factories to a standstill" (Mather, 1974, p. 118). The marching strikers often pulled the plugs from factory boilers to stop work, and the strike therefore became known as the Plug Plot disturbances or riots.

The strike took a more political turn beginning on August 12, when representatives from all trades in the vicinity of Manchester met and resolved to go on strike until the People's Charter was adopted. Three days later, delegates from all over northern England met in Manchester, and 58 of the 85 trades represented voted to strike for the Charter. The government then quickly intervened, sending troops to Lancashire and arresting several of the movement's leaders. Many strikers returned to work after about a week, although some cotton operatives remained on strike until late September (Mather, 1974; Clark, 1953; Charlesworth et al., 1996).

It is understandable that Engels, arriving in Manchester three months after the general strike had begun, saw in it the beginnings of a proletarian revolt. However, most historians now agree that Chartism in Lancashire was largely an economic movement, and that the general strike was "a sudden economic explosion, not the beginning of a planned political revolution." The majority of strikers were more 
interested in "a fair day's wages" than in the adoption of the Charter (Read, 1959, p. 54). Chartism was strongest during the depression years 1838-39, 1841-42, and 1847-48; when economic conditions revived in 1843 and especially after 1848, support for Chartism quickly declined.

Chartism was given "a final lease of life" by the depression of 1847-48, but the Lancashire Chartism of 1848 was much less powerful than in earlier years. When riots occurred in Manchester in March they were repudiated by the Chartist leaders, and when the third petition for the Charter was rejected by Parliament in April, very few disturbances occurred. Ironically, Chartism largely disappeared within a few months of the publication of the Communist Manifesto.

The economic and political situation in the northern industrial cities in the 1840s, and Manchester in particular, elicited concern and alarm from many social critics besides Marx and Engels, and like them, many of the critics "saw catastrophe ahead, not adaptation" (Briggs, 1963, p. 108). In his book Chartism, the essayist and historian Thomas Carlyle wrote that "revolt, sullen revengeful humour of revolt against the upper classes ... is more and more the universal spirit of the lower classes" (1840, p. 41). Three years later, in Past and Present, he added: "with the millions no longer able to live, . . . it is too clear the Nation itself is on the way to suicidal death" (1843 [1977], p. 26) . 5

John Stuart Mill (1848 [1909], p. 751), writing at the same time as Marx and Engels, concluded that "hitherto it is questionable if all the mechanical inventions yet made have lightened the day's toil of any human being. They have enabled a greater population to live the same life of drudgery and imprisonment, and an increased number of manufacturers and others to make fortunes." Mill sounded distincdy like Engels when in 1845 he described Chartism as "the revolt of nearly all the active talent, and a great part of the physical force, of the working classes, against their whole relation to society." Along with the anti-Poor Law movement, Chartism revealed to the middle class "the poverty and wretchedness of great masses of people." Mill (1845 [1967], pp. 369-71) concluded that "itwas no longer disputable that something must be done to render the multitude more content with the existing state of things."

The "condition of England" question also inspired several novels, such as Disraeli's Sybil: or, the Two Nations (1845), and Elizabeth Gaskell's Mary Barton: A Tale of Manchester Life (1848). The reviewer in Fraser's Magazine (1849, p. 430) wrote that Gaskell's novel gave "a detailed insight into the whole 'science of starving,' " and stated that if people wanted to know "why working men turn Chartists and Communists . . . Then let them read Mary Barton. Do they want to know why poor men . . . learn to

\footnotetext{
s Carlyle blamed many of England's social problems, such as Chartism and "trades-strikes," on laissezfaire, and concluded: "Supply-and-demand is not the one Law of Nature; Cash-payment is not the sole nexus of man with man" (1843 [1977], p. 187). Engels wrote very favorably about Past and Present, and in the Communist Manifesto Marx and Engels paraphrase Carlyle when they write that the bourgeoisie "has left remaining no other nexus between man and man than . . . callous 'cash payment'" (1848 [1992], p. 5).
} 
hate law and order, Queen, Lords and Commons,... to hate the rich, in short? Then let them read Mary Barton. Do they want to know what can madden brave, honest, industrious North-country hearts, into self-imposed suicidal strikes, into conspiracy, vitriol-throwing, and midnight murder? Then let them read Mary Barton."

Marx and Engels, therefore, were not alone in asserting that the standard of living of large numbers of workers was quite poor, and perhaps declining in absolute terms, during the "hungry '40s." Nor were they alone in predicting that such living conditions would lead to a revolution by the working class, although they do appear to be the only commentators who believed that revolution was inevitable. The expected revolution, of course, did not occur. ${ }^{6}$ Instead, the threat of revolt greatly diminished after 1848. The decline in tension largely was a result of the improving economic environment and the adoption of various social policies by Parliament, as I will briefly discuss below. It is also possible, however, that the workers that Marx, Engels, and other contemporaries focused their attention on were not representative of the working class as a whole. To get a broader picture of the trend in the economic condition of English workers during the 1830s and 1840s, it is necessary to examine the recent research by economic historians on the standard of living of the working class.

\section{The Standard of Living of the Working Class, 1820-1850}

The debate over what happened to the standard of living of British workers during the industrial revolution is perhaps the longest-running controversy in economic history. Engels's (1845) Condition of the Working Class in England was one of the opening salvos in the debate, the first great "pessimist" study. However, most of the debate has taken place in the 20th century, and a great spurt of research on living standards has been published in the past 15 years, beginning with Lindert and Williamson's (1983) important "optimist" paper. The recent debate has been well-surveyed by Mokyr (1993, pp. 118-30), Lindert (1994), and Engerman (1994). While the ongoing debate examines the longterm trend in living standards from 1750 (or sometimes 1780) to 1851, I want to focus attention only on the period from the end of the post-Napoleonic war slump, around 1820 , to 1851 .

Economic historians have measured movements in living standards in various ways, by examining trends in real wages, per capita income, consumption of partic-

E.P. Thompson $(1964$, pp. 671,817$)$ contends that there also was a serious threat of revolution in the first half of the nineteenth century, especially in 1831-32. The revolution did not occur, according to Thompson (1964, pp. 177, 817, 381), because of the counter-revolution of the ruling classes, the passage of the 1832 Reform Bill, and the rapid growth of Methodism, which was a "component of the psychic process of counter-revolution." On the other hand, Hartwell (1984, p. 68) concludes that "except for a small minority, the workers of England were too sensible to wish for revolution . . . It is their lack of desire for violence which is so obvious to the objective observer." 
ular commodities, life expectancy, infant mortality, and height by age. The current state of the standard of living debate can be quickly summarized. The "economic" measures-real wages and per capita income-indicate that living standards increased sharply from 1820 to 1850 . The "biological" measures, however, tell a different story. Life expectancy at birth remained roughly constant during this period, infant mortality might have increased slightly, and army recruits born around 1850 were shorter than those born around 1820. While the proponents of the biological indicators contend there are important aspects of the standard of living that are not measured by wage data, Engerman (1997) and others caution that there are several problems associated with using height data as a measure of living standards. Recently Crafts (1997) has constructed two new indices which combine economic, biological, and other components of living standards-including literacy rates and civil rights-in an attempt to provide a more comprehensive measure of movements in the "quality of life." Both indices show that living standards improved from 1820 to 1850 , but Crafts (p. 627) admits that "any judgement on 1830 compared with 1850 turns out to be very sensitive to the relative weights given to . . . the demographic indicators."

Table 1 presents seven real wage series for the period 1819-51, three for England and Wales as a whole and four for segments of the cotton industry. ${ }^{7}$ The wage series are each indexed so that the most recent data point, around 1850 (although it differs by series), is set at 100 . The series in the first three columns all show that real wages/earnings of manual workers and their families increased significantly from around 1820 to 1851 , although the series reported by Lindert and Williamson (1983) and Horrell and Humphries (1992) are more "optimistic" than the series reported by Feinstein (1995). The series in columns 4 and 5 show that over this period cotton factory operatives, and the subgroup of adult male cotton spinners, also experienced real wage increases, of 30 percent and 22 percent, respectively. On the other hand, real weekly earnings of handloom weavers declined by 34 percentfrom 1818-20 to 1849-50. In column 7, Brown (1990) estimates that real wages of cotton workers as a whole-factory workers and handloom weavers combinedincreased by 20 percent from $1818-20$ to $1849-50$.

If one focuses on the period from 1830 to $1839-41$, however, a different picture emerges. Feinstein (1995) and Horrell and Humphries (1992) both find that real wages of manual workers increased substantially in the first half of the 1830s, but then fell back in the second half, so that wages around 1840 were nearly identical to those in 1830, as shown in the second and third columns of Table 1 . The period 1839-41 looks even "hungrier," relatively speaking, in the cotton industry. Real wages of cotton factory operatives declined by 14 percent from 1833 to 1839-41 (column 4), while real wages of adult male cotton spinners declined by 12 percent

The cost of living deflators differ across the series. In columns 1, 3, 4, and 5, nominal wages are deflated using Lindert and Williamson's (1985, pp. 148-9) revised cost of living series. In column 3, nominal wages are deflated using Feinstein's (1995, p. 31) cost of living series. In columns 6 and 7, nominal wages are deflated using a cost of living series for northwestern England constructed by Brown (1990, p. 608). 
Table 1

Real Wages of Manual Workers and Lancashire Cotton Workers, 1818-1851

\begin{tabular}{|c|c|c|c|c|c|c|c|}
\hline \multirow[b]{2}{*}{ Year } & \multicolumn{3}{|c|}{ All Manual Workers } & $\begin{array}{l}\text { Factory } \\
\text { Operatives }\end{array}$ & $\begin{array}{c}\text { Cotton } \\
\text { Spinners }\end{array}$ & $\begin{array}{c}\text { Handloom } \\
\text { Weavers }\end{array}$ & \multirow{2}{*}{$\begin{array}{l}\text { All Cotton } \\
\text { Workers }\end{array}$} \\
\hline & $\begin{array}{l}\text { Lindert and } \\
\text { Williamson }\end{array}$ & Feinstein & $\begin{array}{c}\text { Horrell and } \\
\text { Humphries }\end{array}$ & Wood & Wood & Brown & \\
\hline $1816-20$ & & & 58.3 & & & & \\
\hline $1818-20$ & & & & 76.8 & & 151.7 & 83.1 \\
\hline 1819 & 62.0 & & & & & & \\
\hline 1820 & & 74.6 & & & 81.8 & & \\
\hline 1830 & & 77.1 & & & 86.8 & & \\
\hline 1833 & & & & 86.9 & & & \\
\hline $1832-33$ & & & & & & 106.9 & 75.3 \\
\hline $1831-35$ & & & 84.0 & & & & \\
\hline 1835 & 78.0 & 88.9 & & & & & \\
\hline 1836 & & & & 86.5 & 92.1 & 113.8 & 78.7 \\
\hline $1836-40$ & & & 95.0 & & & & \\
\hline 1840 & & 77.4 & & & & & \\
\hline $1839-41$ & & & & 74.6 & & 70.7 & 64.0 \\
\hline 1841 & & & & & 76.3 & & \\
\hline $1841-45$ & & & 84.8 & & & & \\
\hline 1845 & & 90.4 & & 95.3 & & & \\
\hline $1845-46$ & & & & & 94.3 & & \\
\hline $1846-50$ & & & 100.0 & & & & \\
\hline $1849-50$ & & & & 100.0 & 100.0 & 100.0 & 100.0 \\
\hline 1851 & 100.0 & 100.0 & & & & & \\
\hline
\end{tabular}

Sources: For column 1, nominal wage data are from Lindert and Williamson (1983, p. 7). Cost of living estimates are from Lindert and Williamson (1985, pp. 148-9). For column 2, real wage data are from Feinstein (1995, p. 31). For column 3, real wage data are from Horrell and Humphries (1992, p. 870). For columns 4 and 5, nominal wage data are from Wood (1910, pp. 119-20, 28). Cost of living data are from Lindert and Williamson (1985, pp. 148-9). For columns 6 and 7, real wage data are from Brown (1990, p. 610).

from 1830 to 1841 , and by 17 percent from 1836 to 1841 (column 5). Real wages for cotton workers as a whole declined by 15 percent from 1832-33 to 1839-41 (column 7). The decline, however, was short-lived. Real wages increased sharply in the 1840s, so that in 1850-51 wages for all workers except handloom weavers were higher than they had been in 1830 or $1835-36$.

The standard of living of manual workers from 1837 to 1848 looks even worse when unemployment is taken into account. After the boom of 1835-36, the British economy slumped badly in 1837 , largely as a result of a decline in exports to the United States caused by the sharp downturn in the American economy. There was a weak recovery in 1838-39, followed by the severe depression of 1841-42 (Matthews, 1954, pp. 134-43, 206-20). The severity of the downturn was caused by several factors, including: the deficient grain harvests of 1838-41 and the resulting high grain prices, increased grain imports, and balance of payments deficits; the 
severity of the depression in the United States; the sharp fall in profits, a "consequence of earlier decisions ... to expand capacity;" and the decline in railway building after 1840 (Matthews, 1954, pp. 215-17). The recovery that began in 1843 culminated in the prosperous years 1845-46, but another serious downturn followed in 1847-48. The 1847-48 downturn was caused by a sharp increase in grain prices and imports in 1847, which resulted in an outflow of bullion and a sharp increase in interest rates, and by monetary problems caused by the actions of the Bank of England (Boot, 1984).

Unemployment data for this period exist only for a few cities at scattered points in time, and much of the available data are unreliable. As a result, economic historians disagree about the extent of unemployment during the hungry '40s. Hobsbawm (1964, p. 74) claims that the depression of 1841-42 was "almost certainly the worst of the century." Lindert and Williamson (1983, p. 16) disagree, and contend that "non-agricultural unemployment was not exceptionally high in . . . the 1840s." They estimate that in 1842-43, the worst years of depression, the national unemployment rate was equal to 9.4 percent (1983, p. 15). Assuming this estimate is correct, it is still the case that unemployment was higher in the early 1840 s than at any point in the 1820s or 1830s. If the real wages/earnings of employed manual workers were about the same in 1830 and 1840, as the estimates of Feinstein and Horrell and Humphries suggest, then their annual income must have declined, on average, during this period.

The depressions of 1841-42 and 1847-48 were particularly severe in the cotton industry. Profit rates were low from 1837 to 1840, largely because of overinvestment in plant and equipment. When demand declined in 1841-42, firms had few reserves and many went bankrupt and completely stopped production (Matthews, 1954, pp. 137-43). In 1847 the cotton industry experienced a shortage and high price of raw cotton as a result of the poor harvests in the United States in 1845 and 1846. At the same time, domestic demand for cotton goods declined, possibly as a result of declining real wages caused by rising food prices (Boot, 1984, pp. 34-35).

Reasonably reliable unemployment data exist for the cotton industry in Manchester and surrounding towns during both depressions. These data, collected by factory inspectors and The Economist, indicate that unemployment among mill workers was as high as 15-20 percent at the peak of the downturns, and that a significant share of the employed operatives were working short time. ${ }^{8}$ Both factory operatives and handloom weavers experienced a decline in wages and a significant increase in unemployment during the hungry '40s.

The "biological" indicators of the standard of living also suggest that economic conditions deteriorated during the late 1830s and early 1840s. Life expectancy at birth for England as a whole increased from 37.9 years in 1814-18 to 40.8 in $1829-33$, then declined to 40.3 in $1839-43$ and 39.5 in $1849-53$, before increasing

\footnotetext{
" The important role played by short time in the Lancashire cotton industry in the 1840s is discussed in Huberman (1996, Chapter 7). See also Boyer (1990, pp. 240-1).
} 
to 41.2 in 1859-63 (Wrigley and Schofield, 1981, p. 230). The roughly constant life expectancy for England from 1830 to 1860 could be consistent with a decline in average life expectancy for the working class if, as Hollingsworth's (1977) study of the nobility suggests, life chances for the upper classes improved significantly (Linden, 1994, p. 363). On the other hand, Woods (1985, pp. 649-51) argues that the high level of migration from relatively healthy rural areas to unhealthy cities masked an improvement in life chances in both rural and urban areas; he estimates that in cities with populations over 100,000, life expectancy at birth increased by three years from 1831 to 1851 .

The results obtained from studies analyzing height data are less ambiguous about economic conditions in the 1840s. Floud et al. (1990) found that, when smoothing techniques were applied to height data for military recruits, the average heights of "successive birth cohorts of British males" increased from the mid-18th century until 1840, declined during the 1840s, and then rose again after 1850 (Floud and Harris, 1997, p. 101). Johnson and Nicholas (1995) found that males born between 1840 and 1857, and females born between 1845 and 1857, were significandy shorter than those born between 1812 and 1825, even when occupation and location are controlled for. They conclude that "the decline in nutritional status in . . . [the 1840s and 1850s] was quite general" (p. 480).

In sum, while living standards improved over the long run, they declined somewhat during the late 1830s and the 1840s. Lindert and Williamson's (1983, p. 13) conclusion that workers in the 1840s had higher living standards than their grandfathers is certainly correct, but a large share of these same workers had somewhat lower living standards than they had had a decade earlier.

To return to an earlier question: was the trend in living standards during the 1830s and 1840s for cotton workers in south Lancashire, the workers focused on by Marx and Engels, representative of the trend in living standards for British workers as a whole? The answer appears to be a qualified "no." The data reported in Table 1 indicate that manual workers as a whole suffered a decline in real wages from the mid-1830s to the early 1840 s, although their wages in 1840 were about equal to what they had been in 1830. Cotton factory operatives' real wages followed a similar pattern, with one significant difference: in the early 1840s cotton workers' real wages were below what they had been a decade earlier. ${ }^{9}$ Moreover, the depressions of 1841 42 and 1847-48 were especially severe in the cotton districts, and unemployment there was quite high, so that the real wage data understates the relative decline in cotton workers' annual earnings during this period. Finally, south Lancashire was the home of the great losers from technological change: the handloom weavers. In 1841, there were still about 100,000 handloom weavers in Lancashire, representing nearly a third of the labor force in cotton textiles (Brown, 1990, p. 610). The handloom weavers almost certainly were the most poverty stricken group of non-

From 1835 to 1851 wages of cotton spinners declined relative to wages of both skilled manual workers and blue collar workers as a whole (Williamson, 1985, pp. 12, 14). Most, if not all, of this decline must have occurred between 1835 and 1842. 
agricultural workers in England in the 1830s and 1840s, and they were poorer than most agricultural laborers. The combination of falling real wages, high cyclical unemployment, and technological underemployment readily explains the heightened discontent among south Lancashire cotton workers in the 1840s.

Marx and Engels focused their attention on Manchester and the cotton industry because they saw them as representative of the future of England and of the industrialized world, and in this view they were not alone. Many contemporaries viewed Manchester as "the living embodiment of what was happening in and to the modern world" and as the paradigm of what the Industrial Revolution "was portending both for good and bad" (Marcus, 1974, p. 3). In Disraeli's (1844 [1911]) novel Coningsby, when the main character states his desire to visit Athens, his companion replies (p. 95): "The age of ruins is past. Have you seen Manchester?" Manchester was the recognized heart of the Industrial Revolution, and it is not surprising that Marx and Engels, and others, chose to concentrate on the living conditions and "rioting propensities" of workers there.

\section{Why were Marx and Engels's Predictions Wrong?}

The Communist Manifesto was published on the eve of the European revolutions of 1848, which began in Paris on February 22 and soon spread to Austria, Germany and Italy. The revolutions on the continent were caused by a cyclical downturn coinciding with an agricultural crisis and rising political discontent. Revolution did not spread to Britain, which must have surprised not only Marx and Engels but many other contemporary observers as well.

Indeed, after 1848 the chances of a proletarian revolution occurring in Britain greatly diminished, largely as a result of the "Victorian boom" of the 1850s and 1860s. From 1856 to 1873 , Britain's gross domestic product per man-hour grew at an annual rate of 1.3 percent, a rate which was not exceeded until the postwar boom of 1951-73 (Matthews et al., 1982, p. 22). Marx and Engels's assertion in the Manifesto that wages declined as capitalism progressed was proved wrong; living standards increased sharply as a result of the boom. Feinstein (1995, p. 31) estimates that real wages of manual workers increased by 26 percent from 1851 to 1873 , and by 38 percent from 1851 to 1881 . Nor did the recurring cyclical downturns continue to become more severe, as Marx and Engels had predicted. Unemployment during the downturns of 1858 and 1868 was lower than during either downturn of the 1840s. The only years from 1850 to 1914 that might have rivaled $1841-42$ in terms of unemployment were 1879 and $1885-86 .^{10}$

There was no revival of Chartism after 1848. During the Victorian boom skilled

\footnotetext{
'" Estimates of annual unemployment rates from 1855 to 1914 are available in Feinstein (1972, Table 57). The estimates were calculated from trade union records and might not be representative of the rate of unemployment for the labor force as a whole, especially before 1892. See Feinstein (pp. 225-6).
} 
workers turned their attention instead to the formation of large national craft unions. The first "New Model" union was the Amalgamated Society of Engineers, founded in 1851. Workers in several other fields soon organized along similar lines. The New Model unions were less politically ambitious than most earlier unions, and more cautious in the use of strikes, which their leaders viewed as "doubleedged weapon [s]" (Pelling, 1987, p. 53). The Webbs (1920, p. 179) concluded that the New Model unions substituted, "wherever possible, . . . Industrial Diplomacy for the ruder methods of the Class War." Besides striving to increase wages and improve working conditions, many unions also provided their members with various insurance benefits, which reduced or even eliminated the need for members to ever apply for poor relief (Boyer, 1988).

The increasing prosperity of the working class and the decline in worker militancy both went against the predictions in the Communist Manifesto. Marx and Engels reached overly pessimistic conclusions about the economic plight of the working class and overestimated the potential for a proletarian revolution largely because they were writing during the hungry '40s and because they focused their attention on the cotton industry in south Lancashire. They concentrated on the cotton industry because they viewed it as the apogee of industrial capitalism, the place where "the effects of modern manufacture upon the working class" were "most freely and perfectly" developed (Engels, 1845 [1987], pp. 82-3).

They interpreted the downturn of 1837-42 and the political discontent that it spawned in industrial cities as evidence that cyclical downturns became "more violent, more terrible" over time, and therefore that British capitalism could not long survive. The fact that the cotton industry was particularly hard hit by the downturns of 1841-42 and 1847-48, and that Chartism and other forms of political agitation were centered in the northern industrial cities, provided further evidence for Marx and Engels that a revolt of the proletariat was soon to occur.

However, their pessimistic predictions were not simply a result of their observations of the British economy in the 1840s but were also due to their analysis of the British political system. Marx and Engels (1848 [1992], pp. 5, 27) argued that the adoption of the Reform Act of 1832, which enfranchised middle class property holders and redistributed the seats in Parliament, caused the aristocracy to succumb to the "hateful upstart" bourgeoisie, who thereby achieved "exclusive political sway." As evidence of the bourgeoisie's control of Parliament, Engels (1845 [1987]) cited the adoption of the New Poor Law in 1834 and, more importantly, the repeal of the Corn Laws in 1846. This depiction of British politics in the second quarter of the 19th century is largely incorrect. While the Reform Act significantly increased the representation of the northern industrial cities in the House of Commons, Parliament continued to be dominated by the aristocracy and gentry for several decades after 1832. In the 1840s "between 70 and 80 per cent of the Commons . . . came from the landed interest" (Evans, 1983, p. 216). These landowners supported the New Poor Law, and were instrumental in its passage (Brundage, 1978, chapter 3; Boyer, 1990, pp. 194-204).

The repeal of the Corn Laws eliminated the tariff on imported grain, and was 
indeed a triumph for the bourgeoisie and its Manchester-based pressure group, the Anti-Corn Law League. Yet the Corn Laws were repealed by a Parliament in which landowners still held a majority of seats. Eric Evans (1983, p. 269) concluded that by 1846 "a substantial proportion of the landed interest no longer set great store by protection" and, in any case, the demand for bread by "Britain's swollen population" made protection no longer tenable.

Moreover, Parliament during the same period adopted a variety of acts regulating the employment of children and women, many of which were opposed by manufacturers, who waged an "aggressive rearguard action against factory legislation" in the 1830s and 1840s (Howe, 1984, pp. 178-89). The Factory Act of 1833 eliminated the employment of children under age 9 in cotton and woolen mills, and set maximum hours of work for children and youths aged 9-17. The Ten Hours Act of 1847 restricted the employment of women and young persons in factories initially to eleven hours per day and after a year to ten hours. The 1842 Mines Act and the Factory Acts of 1844, 1850, 1853, 1867, 1874, and 1878 further restricted the employment of children and young persons and regulated the employment of adult women. The 1874 Act effectively established a ten-hour work day for adult males. The problems of urban squalor were addressed by the Public Health Act of 1848 and similar acts in 1859, 1866, and 1872, and by the Artisans' and Labourers' Dwellings Acts of 1868 and 1875. Unions were given legal recognition by the Trade Union Act of 1871, and an act of 1875 legalized peaceful picketing. Perhaps most significant, the 1867 Reform Act more than doubled the urban electorate by extending the franchise to the better-paid members of the working class.

As the increasingly interventionist stance of the government from the 1840s onwards makes clear, Marx and Engels's analysis of British politics and society was greatly oversimplified. There was not, even during the hungry '40s, a "veiled civil war" raging between the capitalists and the workers. Nor was there either a unified middle class or a unified working class, as Marx and Engels asserted. There were significant differences in income and oudook between the capitalist middle class, the lower middle class of shopkeepers, clerks, and others, and the professional middle class of doctors, clergymen, lawyers, and public officials. The debate within urban town councils over the adoption of sanitary improvements offers an example of the political differences between the capitalist and the professional middle class, on one hand, and the lower middle class, on the other (Hennock, 1963; Wohl, 1983, ch. 7).

Similarly, the working class must be divided into at least two groups - the "labor aristocracy" of highly skilled artisans and the remainder of the manual workers. John Stuart Mill wrote (1848 [1909], p. 393) that "the line of demarcation" between different classes of workers was so complete "as to be almost equivalent to an hereditary distinction of caste." Some historians contend that the labor aristocracy "should be grouped with the middle class[,] many of whose prejudices about keeping down the rates and maintaining social order they probably shared, and a large gap should be marked between them and the mass" of manual workers (Clark, 1966, p. 132). Chartism offers an example of the differences in outlook within the working class. Its support came largely from "the casualties of the industrial changes 
of the period." The labor aristocracy was not much involved with Chartism, except during times of "intense trade depression," and the trade unions never became "part and parcel of the Movement" (Pelling, 1987, pp. 34-35; Musson, 1972, pp. 45-48; Webb and Webb, 1920, pp. 174-77).

How did Marx and Engels respond to the economic and political developments in England after 1848? According to Hobsbawm (1975, p. 108), they "maintained some hope of a revived revolution after 1849, . . . then put their faith in the next major economic crisis (that of 1857), [and] resigned themselves to the long haul thereafter." Possibly the best statement of their later views was written by Engels in 1885, two years after Marx's death. Engels admitted that 1848 was the beginning of "a new industrial epoch." The manufacturing capitalists now controlled national politics, but the experience of Chartism had taught them that they could "never obtain full social and political power over the nation except by the help of the working class." As a result, the manufacturers gradually came to support the Factory Acts, trade unions, and even the franchise for the working class (1885 [1971], pp. 389-90). The condition of the factory operatives and the members of the "great trade unions" permanently improved after 1850. However, for the majority of workers, "the state of misery and insecurity in which they live now is as low as ever, if not lower" (pp. 391-92). Moreover, the relatively high living standards of the factory workers were a result of "England's industrial monopoly," which would soon be "irretrievably broken up" by the economic rise of Germany, France and America. The working class then will lose its "privileged position . . . [relative to] its fellow-workers abroad. And that is the reason why there will be Socialism again in England" (pp. 393-94).

Despite this prediction, in their letters Marx and Engels were very critical of the British working class. Marx wrote in 1878 that the working class "had at last got to the point when it was nothing more than the tail of the Great Liberal Party, i.e., of the oppressors, the capitalists." In 1894, a year before his death, Engels wrote: "One is indeed driven to despair by these English workers . . . with their essentially bourgeois ideas and viewpoints, with their 'practical' narrow-mindedness" (Marx and Engels, 1953, pp. 509, 537). As their hopes for a proletarian revolution in Britain, or elsewhere in western Europe, declined, Marx and Engels in the late 1870s began to turn their attention to Russia (McLellan, 1973, pp. 438-42). It was there, 22 years after the death of Engels, that a communist revolution finally occurred.

- / thank Brad De Long, Stanley Engerman, Alan Krueger, Peter Lindert, Andrew Rutten, Nick Salvatare, Timothy Taylor, and Jeffrey Williamson for helpful comments on an earlier draft. 


\section{References}

Adshead, Joseph, Distress in Manchester: Evidence of the state of the Labouring Classes in 184042. London: Henry Hooper, 1842.

Berg, Maxine, "Factories, Workshops, and Industrial Organisation." In Floud, Roderick, and D. N. McCloskey, eds., The Economic History of Britain since 1700, 2nd edition, Vol. 1. Cambridge, UK- Cambridge University Press, 1994, 123-50.

Boot, H. M., "Unemployment and Poor Law Relief in Manchester, 1845-50," Social History, May 1990, /5;\% 217-28.

Boot, H. M., The Commercial Crisis of 1847. Hull: Hull University Press, 1984.

Boyer, George R., An Economic History of the English Poor Law, 1750-1850. Cambridge, UK Cambridge University Press, 1990.

Boyer, George R., "What Did Unions Do in Nineteenth Century Britain?" Journal of Economic History, June 1988, 4S;\% 319-32.

Briggs, Asa, Victorian Cities. London: Odhams Press, 1963.

Brown, John, "The Condition of England and the Standard of Living: Cotton Textiles in the Northwest, 1806-1850," Journal of Economic History, September 1990, 50\$, 591-614.

Brundage, Anthony, The Making of the New Poor Law, 1832-9. London: Hutchinson, 1978.

Bythell, Duncan, The Handloom Weavers. Cambridge, UK: Cambridge University Press, 1969.

Carlyle, Thomas, Chartism. London: James Fraser, 1840.

Carlyle, Thomas, Past and Present. New York: New York University Press, 1977. Originally published 1843.

Chadwick, Edwin, Report on the Sanitary Condition of the Labouring Population of Gt. Britain. Edinburgh: Edinburgh University Press, 1965. Originally published 1842 .

Charlesworth, Andrew, et al., An Atlas of Industrial Protest in Britain 1750-1990. London: Macmillan, 1996.

Clark, G. Kitson, The Making of Victorian England. New York: Atheneum, 1966.

Clark, G. Kitson, "Hunger and Politics in 1842," Journal of Modem History, December 1953, 25:4, 355-74.

Crafts, N. F. R., "Some Dimensions of the 'Quality of Life' During the British Industrial Revolution," Economic History Review, November 1997, 50.4, 617-39.

Crafts, N. F. R., British Economic Growth During the Industrial Revolution. Oxford: Clarendon Press, 1985.
Crouzet, F., The First Industrialists: The Problem of Origins. Cambridge, UK Cambridge University Press, 1985.

Disraeli, Benjamin, Coningsby London: Dent, 1911. Originally published 1844.

Edsall, Nicholas, The Anti-Poor Law Movement 1834-44. Manchester: Manchester University Press, 1971.

Engels, Friedrich, The Condition of the Working Class in England. Harmondsworth, UK Penguin Books, 1987. Originally published 1845 .

Engels, Frederick, "England in 1845 and in 1885." In Marx, Karl, and Frederick Engels, Articles on Britain. Moscow: Progress Publishers, 1971, 388-94. Originally published 1885 .

Engerman, Stanley, ' 'The Standard of Living Debate in International Perspective: Measures and Indicators." In Steckel, Richard, and Roderick Floud, eds., Health and Welfare during Industrialization. Chicago: University of Chicago Press, 1997, 17-45.

Engerman, Stanley,' 'Reflections on 'The Standard of Living Debate': New Arguments and New Evidence." In James, John, and Mark Thomas, eds., Capitalism in Context. Chicago: University of Chicago Press, 1994, 50-79.

Feinstein, Charles, "Changes in Nominal Wages, the Cost of Living and Real Wages in the United Kingdom over Two Centuries, 17801990." In Scholliers, P. and V. Zamagni, eds., Labour's Reward. Aldershot, UK Edward Elgar, 1995, 3-36.

Feinstein, Charles, National Income, Expenditure, and Output of the United Kingdom, 1855-1965. Cambridge, UK Cambridge University Press, 1972.

Floud, Roderick, et al., Health, Height and History: Nutritional Status in the United Kingdom, 17501980. Cambridge, UK Cambridge University Press, 1990.

Floud, Roderick, and Bernard Harris, "Health, Height, and Welfare: Britain, 1700-1980." In Steckel, Richard, and Roderick Floud, eds., Health and Welfare during Industrialization. Chicago: University of Chicago Press, 1997, 91-126.

Eraser's Magazine, "Review of Mary Barton," April 1849, 39, 429-32.

Hammond, J. L., and Barbara Hammond, The Skilled Labourer. London: Longmans, 1919.

Hartwell, R. M., "La revolution manquee." In Coleman, D. C, and Peter Mathias, eds., Enterprise and History. Cambridge, UK Cambridge University Press, 1984, 52-68.

Henderson, W. O., The Life of Friedrich Engels, volume 1. London: Frank Cass, 1976. 
Henderson, W. O., and W. H. Chaloner, "Editors' Introduction." In Engels, Friedrich, The Condition of the Working Class in England. Oxford: Basil Blackwell, 1958.

Hennock, E. P., "Finance and Politics in Urban Local Government in England, 1835-1900," The Historical Journal, 1963, 6:2, 212-25.

Himmelfarb, Gertrude, The Idea of Poverty: England in the Early Industrial Age. New York: Knopf, 1984.

Hobsbawm, Eric, The Age of Capital New York: Scribner's, 1975.

Hobsbawm, Eric, Labouring Men. London: Weidenfeld and Nicolson, 1964

Hollingsworth, T. H., "Mortality in the British Peerage Families Since 1600," Population, September 1977, 32, 323-52.

Horrell, Sara, and Jane Humphries, "Old Questions, New Data, and Alternative Perspectives: Families' Living Standards in the Industrial Revolution," Journal of Economic History, December 1992, 52:4, 849-80.

Howe, Anthony, The Cotton Masters 1830-1860. Oxford: Clarendon Press, 1984.

Huberman, Michael, Escape from the Market: Negotiating Work in Manchester. Cambridge, UK: Cambridge University Press, 1996.

Johnson, Paul, and Stephen Nicholas, "Male and Female Living Standards in England and Wales, 1812-1857: Evidence From Criminal Height Records," Economic History Review, August 1995, 483, 470-81.

Kay, James, The Moral and Physical Condition of the Working Classes employed in the Cotton Manufac ture in Manchester, 2nd edition. London: James Ridgway, 1832.

Knott, John, Popular Opposition to the 1834 Poor Law. New York: St. Martins, 1986.

Lindert, Peter, "Unequal living standards." In Floud, Roderick, and D. N. McCloskey, eds., The Economic History of Britain since 1700, 2nd edition, Vol. 1. Cambridge, UK: Cambridge University Press, 1994, 357-86

Lindert, Peter, and Jeffrey Williamson, "English Workers' Real Wages: Reply to Crafts," Journal of Economic History, March 1985, 45:1, 145-53.

Lindert, Peter, and Jeffrey Williamson, "English Workers' Living Standards During the Industrial Revolution: A New Look," Economic History Review, February 1983, 36:1, 1-25.

Lloyd-Jones, R., and A. A. Le Roux, "The Size of Firms in the Cotton Industry, Manchester, 1815-41," Economic History Review, February 1980, 33:1, 72-83.

Lyons, John, "Family Response to Economic Decline: Handloom Weavers in Early Nine-
teenth-Century Lancashire," ResearchinEconomic History, 1989, 12, 45-91.

McCloskey, D. N., "The Industrial Revolution 1780-1860: a Survey." In Floud, Roderick, and D. N. McCloskey, eds., The Economic History of Britain since 1700, Vol. 1. Cambridge, UK: Cambridge University Press, 1981, 103-27.

McLellan, David, "Introduction." In Engels, Friedrich, The Condition of the Working Class in England. Oxford: Oxford University Press, 1993.

McLellan, David, Karl Marx: His Life and Thought. New York: Harper and Row, 1973.

Marcus, Stephen, Engels, Manchester and the Working Class. New York: Random House, 1974.

Mather, F. C, "The General Strike of 1842." In Quinault, R., and J. Stevenson, eds., Popular Protest and Public Order. London: Allen and Unwin, 1974, 115-40.

Marx, Karl, and Friedrich Engels, The Cотmunist Manifesto. Oxford: Oxford University Press, 1992. Originally published 1848 .

Marx, Karl, and Frederick Engels, On Britain. Moscow: Foreign Languages Publishing House, 1953

Matthews, R. C. O., A Study in Trade-Cycle History: Economic Fluctuations in Great Britain, 1833 1842. Cambridge, UK: Cambridge University Press, 1954

Matthews, R. C. O., et al., British Economic Growth, 1856-1973. Stanford: Stanford University Press, 1982.

Mill, John Stuart, Principles of Political Economy London: Longmans, 1909. Originally published 1848.

Mill, John Stuart, "The Claims of Labour." In Collected Works of John Stuart Mill, Vol. TV: Essays on Economics and Society. Toronto: University of Toronto Press, 1967, 365-89. Originally published 1845.

Mokyr, Joel, "Editor's Introduction: The New Economic History and the Industrial Revolution." In Mokyr, Joel, ed., The British Industrial Revolution: An Economic Perspective. Boulder: Westview Press, 1993, 1-131.

Musson, A. E., British Trade Unions, 1800-1875. London: Macmillan, 1972.

Petting, Henry, A History of British Trade Unionism, 4th edition. London: Macmillan, 1987.

Read, Donald, "Chartism in Manchester." In Briggs, Asa, ed., Chartist Studies. London: Macmillan, 1959, 29-54.

Rose, Michael E., "The Allowance System under the New Poor Law," Economic History Review, December 1966, 19.3, 607-20.

Schumpeter, Joseph, ' 'The Communist Manifesto in Sociology and Economics," Journal of Political Economy, June 1949, 57:3, 199-212. 
Struik, Dirk, Birth of the Communist Manifesto. New York: International Publishers, 1971.

Taylor, A. J. P., "Introduction." In Marx, Karl and Friedrich Engels, The Communist Manifesto. Harmondsworth, UK- Penguin Books, 1967.

Thompson, E. P., The Making of the English Working Class. New York: Pantheon, 1964.

Tocqueville, Alexis de, Journeys to England and Ireland. New Haven: Yale University Press, 1958.

Webb, Sidney, and Beatrice Webb, The History of Trade Unionism. London: Longmans, 1920.
Williamson, Jeffrey G., Did British Capitalism Breed Inequality? Boston: Allen and Unwin, 1985.

Wohl, A. S., Endangered Lives: Public Health in Victorian Britain. Cambridge: Harvard University Press, 1983.

Wood, George H., The History of Wages in the Cotton Trade During the Past Hundred Years. London: Sherrat and Hughes, 1910.

Wrigley, E. A. and R. S. Schofield, The Population History of England, 1541-1871. Cambridge: Harvard University Press, 1981. 